Bibliotech : Jurnal Ilmu Perpustakaan dan Informasi, 3 (2) 2018

\title{
KERJASAMA PARTISIPATIF PENGEMBANGAN BAHASA INDEKS ONLINE PADA PROYEK VOCABULARY CONTROL NUSANTARA
}

\author{
Waris Agung Widodo ${ }^{1}$ * \\ ${ }^{1}$ Universitas Terbuka \\ *Korespondensi: ido.alit@gmail.com
}

\begin{abstract}
ABSTRAK
Bahasa indeks diperlukan dalam kegiatan pengindeksan subjek untuk mempermudah temu kembali informasi. Bahasa indeks merupakan sebuah daftar dari kumpulan subjek beserta hubungan antar subjek-subjek tersebut. Salah satu contoh bahasa indeks adalah Daftar Tajuk Subjek Perpustakaan Nasional (DTS Perpusnas) yang disebarkan atau dibagikan oleh Perpustakaan Nasional Republik Indonesia dalam bentuk buku elektronik. Implementasi DTS Perpusnas dalam proses pengolahan koleksi perpustakaan belum terintegrasi dalam sistem otomasi perpustakaan. Oleh sebab itu, perlu adanya upaya untuk mempermudah implementasi bahasa indeks khususnya DTS Perpusnas. Saat ini, ada sebuah gerakan yang bertujuan untuk membangun bahasa indeks dalam bentuk basis data. Gerakan ini dinamakan Proyek Vocabulary Control Nusantara (ValCoN) yang sifatnya terbuka dan partisipatif. Siapa saja dapat berpartisipasi dalam gerakan ini dan ikut serta membangun basis data bahasa indeks. Beragamnya latar belakang partisipan gerakan ini menimbulkan permasalahan ketika partisipan yang bergabung belum memahami cara kerjanya. Hal ini dapat menyebabkan kosakata terkendali hasil kegiatan proyek ValCoN tidak seragam kualitasnya. Oleh sebab itu, artikel ini dibuat untuk memberikan gambaran tentang kerjasama pengembangan model bahasa indeks secara partisipatif melalui ValCoN. Kajian ini menggunakan metode penelitian deskriptif. Pengambilan data dilakukan dengan cara observasi. Hasil kajian ini dapat digunakan sebagai pedoman oleh para partisipan dalam menyelesaikan proyek ValCoN.
\end{abstract}

Kata kunci: Bahasa indeks; daftar tajuk subjek; katalogisasi; fitur otomasi perpustakaan.

\section{PENDAHULUAN}

Pengindeksan koleksi perpustakaan mencakup kegiatan-kegiatan pembuatan indeks dan sejenisnya seperti katalog dan bibliografi yang bertujuan untuk mempermudah temu kembali informasi. Bahasa merupakan unsur utama dalam temu kembali informasi, baik yang tersusun dalam bentuk abjad istilah maupun menurut kelas berdasarkan urutan notasi. Temu kembali tidak hanya mengandalkan penggunaan bahasa secara umum, perlu adanya modifikasi terkait dengan kosakata maupun sintaksis sehingga perlu diciptakan bahasa terkendali yaitu bahasa indeks. Terdapat dua jenis bahasa indeks yaitu bahasa indeks nonverbal berupa skema / bagan klasifikasi dan bahasa indeks verbal berupa daftar tajuk subjek dan tesaurus (Purwono, 2011).

Tajuk Subjek merupakan deskriptor yang dibentuk dari kata tunggal atau kata majemuk, dipilih secara empiris dari teks dokumen dengan tujuan memori pada tingkat 
Bibliotech : Jurnal Ilmu Perpustakaan dan Informasi, 3 (2) 2018

ketepatan yang moderat berbagai subjek yang diliput unit informasi. Karena masing-masing deskriptor bebas satu dari yang lain, tajuk subjek disebut pula bahasa kombinasi. Daftar tajuk subjek biasanya menyertakan juga acuan silang atau acuan "lihat juga" sehingga tercipta hubungan antar subjek (Sulistyo-Basuki, 2011). Salah satu contoh bahasa indeks adalah Daftar Tajuk Subjek Perpustakaan Nasional (DTS Perpusnas) yang disebarkan atau dibagikan oleh Perpustakaan Nasional Republik Indonesia dalam bentuk buku elektronik. Implementasi DTS Perpusnas dalam proses pengolahan koleksi perpustakaan belum terintegrasi dalam sistem otomasi perpustakaan. Oleh sebab itu, perlu adanya upaya untuk mempermudah implementasi bahasa indeks khususnya DTS Perpusnas. Upaya tersebut antara lain mengubah format DTS Perpusnas dari bentuk Portable Document Format (PDF) menjadi XML (Extensible Markup Language) seperti MeSH yang diterbitkan oleh NLM (National Library of Medicine) atau menjadi Linked Data Service seperti Library of Congress Subject Headings.

Saat ini, ada sebuah gerakan yang bertujuan untuk membangun bahasa indeks dalam bentuk basis data online. Basis data bahasa indeks itu nantinya dapat dikembangkan menjadi XML maupun Linked Data Service. Gerakan ini dinamakan proyek Vocabulary Control Nusantara (ValCoN) yang sifatnya terbuka dan partisipatif (Kangko, 2016). ValCoN dapat diakses di http://slimsjakarta.web.id/vocabulary atau http://vocabulary.slimsjakarta.web.id. Siapa saja dapat bergabung menjadi partisipan dalam gerakan ini dan ikut membangun basis data bahasa indeks.

Beragamnya latar belakang partisipan gerakan ini menimbulkan permasalahan ketika partisipan yang bergabung belum memahami cara kerjanya. Hal ini dapat menyebabkan kosakata terkendali hasil kegiatan proyek ValCoN tidak seragam kualitasnya. Oleh sebab itu, artikel ini dibuat untuk memberikan gambaran tentang kerjasama pengembangan model bahasa indeks secara partisipatif melalui ValCoN.

\section{METODE}

Kajian ini menggunakan metode penelitian deskriptif. Penelitian deskriptif bertujuan untuk menggambarkan atau mendeskripsikan suatu karakter atau fungsi dari sesuatu hal (Hasibuan, 2007). Pengambilan data dilakukan dengan cara observasi langsung partisipatif. Artikel ini hanya membatasi pembahasan penggunaan DTS Perpusnas di dalam sistem ValCoN. Dalam prosesnya, digunakan mesin perambah web berupa Google Chrome versi 54.0.2840.99 serta aplikasi proyek ValCoN versi 1.3.2. 
Bibliotech : Jurnal Ilmu Perpustakaan dan Informasi, 3 (2) 2018

\section{HASIL DAN PEMBAHASAN}

Pembahasan akan dibagi menjadi 2 bagian, yaitu pembahasan fitur serta pembahasan alur kerja pada ValCoN. Proyek ValCoN dapat diakses melalui perabaan web yang terhubung dengan jaringan internet melalui alamat URL http://slimsjakarta.web.id/vocabulary atau http://vocabulary.slimsjakarta.web.id.

\subsection{Fitur-Fitur}

Fitur yang ada pada ValCoN terdiri dari fitur-fitur yang ada di halaman Homepage dan Backend. Fitur pada halaman Homepage dapat diakses oleh semua orang sedangkan fitur halaman Backend hanya dapat diakses oleh partisipan yang sudah mendaftarkan diri (register). Para partisipan dapat berpartisipasi membangun bahasa indeks pada ValCoN melalui halaman Backend

Homepage merupakan halaman utama/halaman pembuka sebuah situs web. Saat proyek ValCoN pertama kali terbuka akan ditampilkan halaman yang sederhana dengan beberapa menu navigasi yaitu Register, Login, dan About. Menu Register digunakan untuk menampilkan halaman pendaftaran. Pada halaman ini akan ditampilkan formulir pendaftran dengan ruas-ruas informasi yang dibutuhkan dalam keanggotaan. Beberapa ruas informasi tersebut antara lain username, full name, email, phone, dan password. Menu Login menampilkan halaman Login dengan terdapat Form Login yang terdiri dari ruas username dan password. Menu About menampilkan informasi nama aplikasi, hak cipta kepengarangan aplikasi, serta versi dari aplikasi.

Backend merupakan halaman belakang dari aplikasi. Diperlukan Login untuk masuk ke dalam halaman ini. Halaman Backend merupakan tempat dilakukannya kegiatan penginputan subjek. Halaman Backend aplikasi tidak banyak terdapat perbedaan pada tampilan. Pada bagian atas kiri terdapat menu Dashboard dan menu Topic. Pada bagian kanan atas menu Registrasi \& Login tidak ada dan diganti oleh menu dropdown dengan informasi username yang saat ini sedang login. Jika username tersebut di klik akan muncul menu Profile serta Logout.

Menu Dashboard menampilkan statistik dari hasil penginputan subjek, lihat Gambar1. Informasi ditampilkan dengan element kotak-kotak. Dengan icon yang mewakili informasi dengan latar belakang warna berbeda-beda. Statistik yang tersedia antara lain jumlah subjek keseluruhan yang sudah diinput, jumlah relasi subjek, jumlah subjek yang terelasi dengan subjek lain, serta jumlah subjek yang diinput oleh anggota yang saat itu login. 


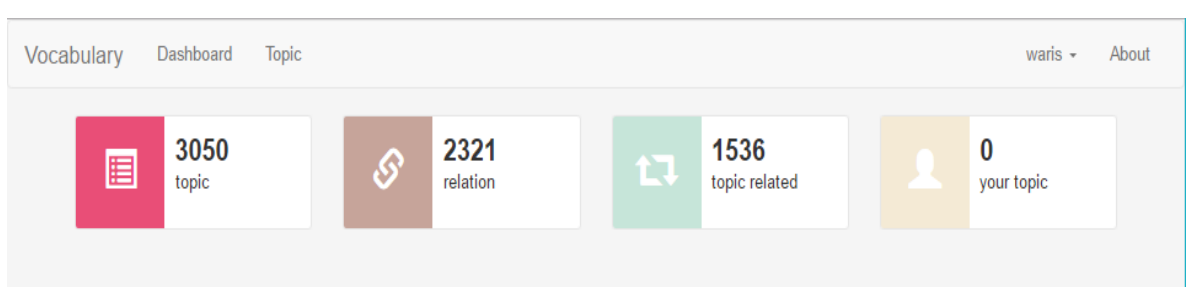

Gambar 1. Tampilan halaman dashboard.

Menu Profile menampilkan halaman Profile dari anggota. Pada halaman Profile terdapat tiga kolom yang masing masing kolom menampilkan informasi yang berbeda. Pada kolom pertama sebelah kiri menampilkan foto, nama, kepangkatan akun, jumlah topik yang sudah diinput, jumlah relasi antar topik yang sudah dilakukan, serta jumlah topik yang diinput pada hari ini. Pada kolom kedua terdapat formulir untuk meyunting atau memperbaharui dan juga melengkapi informasi tentang akun. Terdapat informasi tambahan yang diminta, antara lain Full Name (nama lengkap) dan image. Gambar profile yang diizinkan untuk diunggah maksimal berukuran 500kB. Untuk mengubah password akun juga dapat dilakukan pada halaman profile ini. Pada kolom berikutnya terdapat ruang untuk informasi dari sistem. Menu Logout digunakan untuk keluar dari halaman Backend.

Saat Menu Topic dibuka akan menampilkan daftar subjek yang sudah diinputkan. Subjek ditampilkan dengan menggunakan tabel yang terdiri dari beberapa kolom, di ataranya:
a. Topic, menampilkan nama subjek.
b. Topic type, menampilkan jenis subjek apakah berupa subjek topik, geografis, nama, masa, aliran atau pekerjaan.
c. Classification, menampilkan notasi klasifikasi.
d. Input date, menampilkan tanggal penginputan.
e. Action, berisi tombol-tombol aksi seperti View, Edit dan Delete.
Daftar subjek dibuat paginasi dengan menampilkan 10 cantuman secara default. Terdapat opsi berapa cantuman yang dapat ditampilkan dalam halaman, yaitu 10, 25, 50 dan 100 cantuman. Untuk memudahkan perpindahan halaman cantuman terdapat deret tombol halaman (paging) yang terdapat pada kanan bawah tabel. Untuk mencari subjek tertentu terdapat form pencarian yang terdapat pada kanan atas tabel. Saat keyboard memasukan kata kunci pada form pencarian maka sistem secara otomatis akan melakukan sebuah pencarian untuk kata kunci yang dimasukan. 


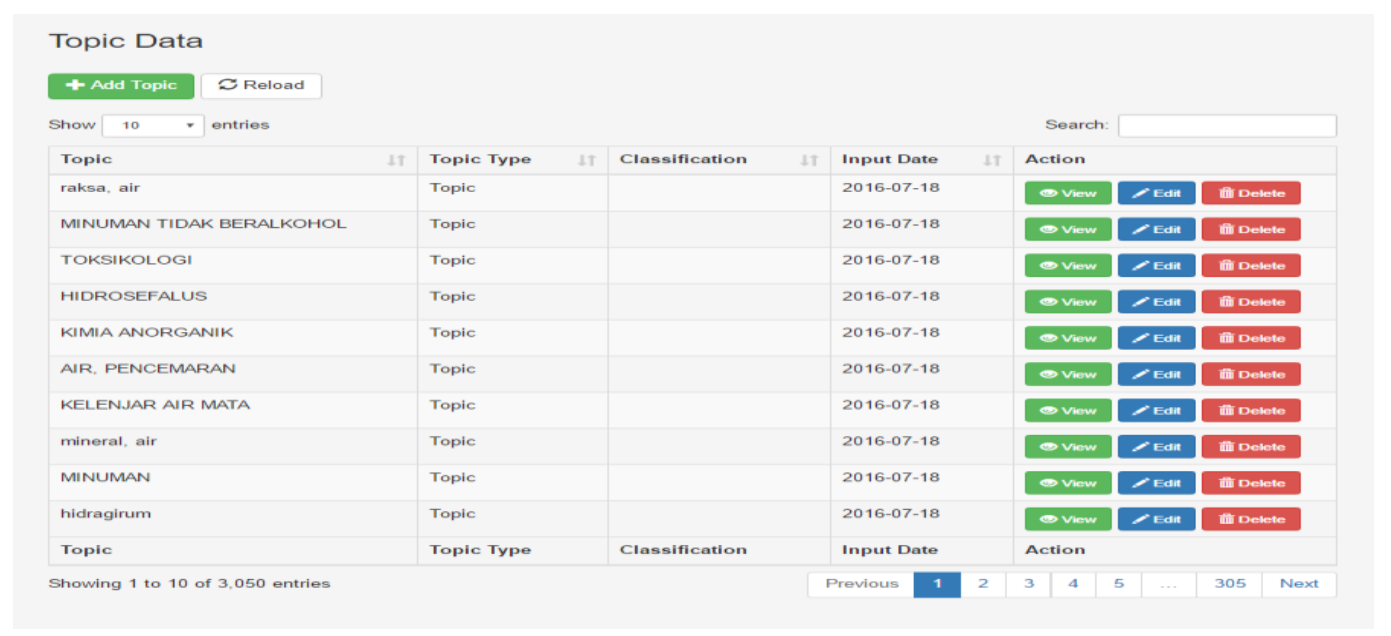

Gambar 2. Daftar subjek yang sudah diinputkan.

Pada kanan atas tabel terdapat tombol Add Topic dan Reload (berfungsi untuk memperbaharui daftar subjek secara manual). Tombol Add Topic digunakan untuk menambah subjek baru. Saat tombol ini diklik akan menampilkan popup berupa form isian untuk menambahkan subjek baru. Terdapat ruas yang harus diisi diantaranya Topic, Classification Code, Topic Type, Auth List. Pada ruas Topic diisikan subjek baru, Classification Code diisikan nomer/notasi klasifikasi DDC. Topic Type berupa dropdown dengan beberapa nilai, yaitu topic, geografis, nama, aliran serta pekerjaan. Auth List secara default bernilai "Tajuk Subjek Perpusnas", hal ini dikarenakan projek ValCoN ini menggunakan DTS Perpusnas sebagai acuan subjek yang diinputkan, lihat Gambar2.

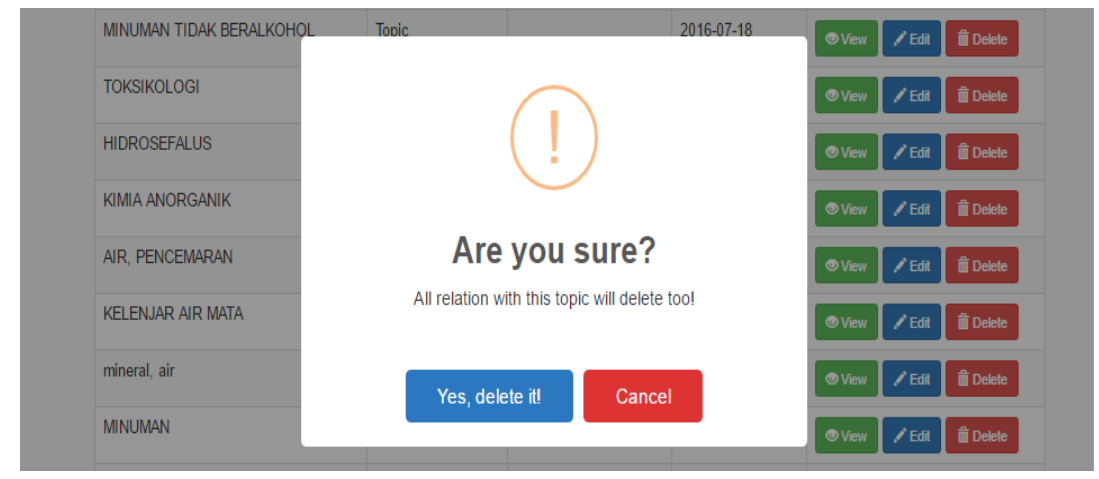

Gambar 3. Peringatan akan muncul saat akan menghapus sebuah subjek.

Tombol-tombol action pada tiap-tiap subjek memiliki fungsi yang berbeda. Tombol View digunakan untuk melihat relasi dari subjek tersebut. Tombol Edit digunakan untuk menyunting subjek jika terdapat kekeliruan, serta tombol Delete digunakan untuk menghapus subjek. Saat sebuah subjek dihapus maka semua relasi yang ada untuk subjek tersebut akan terhapus juga, lihat Gambar 3. Dalam halaman ini juga dapat dilihat relasi antar kata yang sudah terbentuk seperti pada Gambar 4. 
Bibliotech : Jurnal Ilmu Perpustakaan dan Informasi, 3 (2) 2018

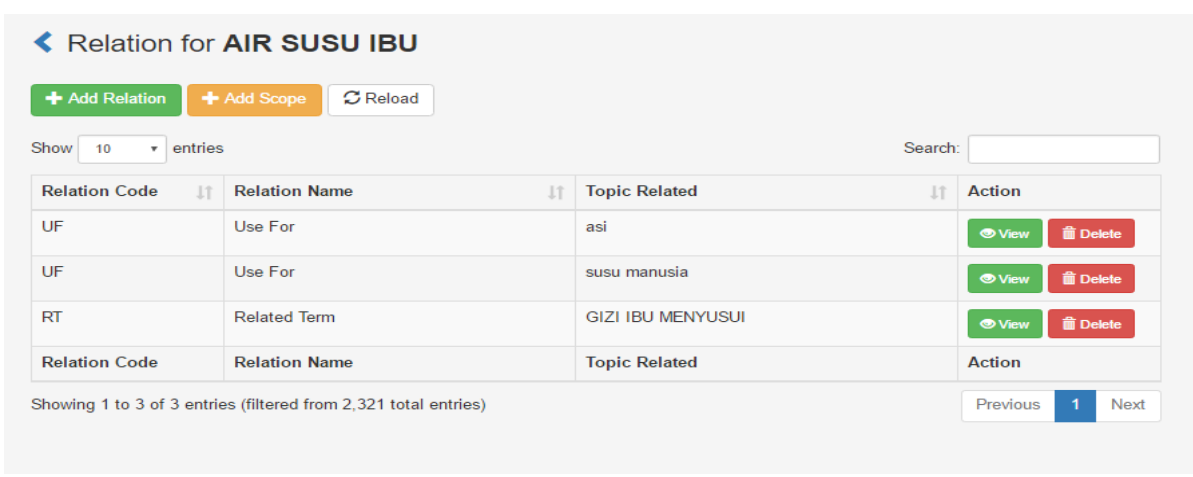

Gambar 4. Relasi sebuah subjek.

\subsection{Alur Kerja}

Pembahasan alur kerja mencakup alur pendaftaran dan alur penginputan subjek. Partisian memerlukan username dan password untuk dapat masuk ke halaman Backend. Dengan demikian, pendaftaran perlu dilakukan oleh partisipan sebelum dapat memulai penginputan subjek. Alur pendaftaran terdiri dari 5 langkah, lihat Gambar 5.

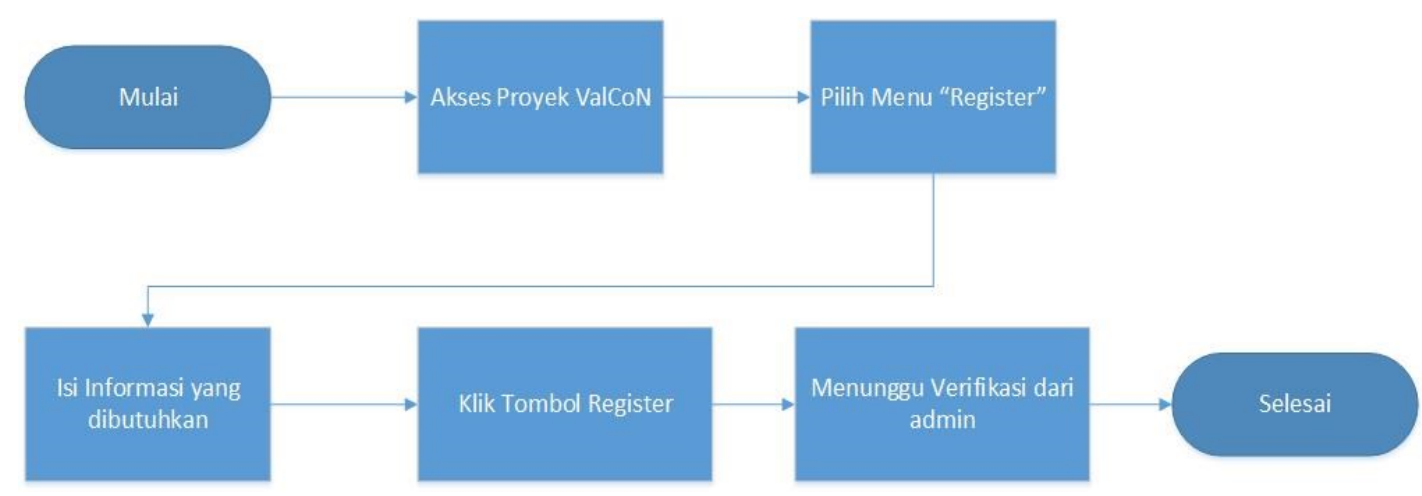

Gambar 5. Diagram alur pendaftaran.

Registrasi/pendaftaran sebagai partisipan proyek ValCoN dapat dilakukan dengan mengakases Menu Register di alamat http://slimsjakarta.web.id/vocabulary/register. Data yang perlu diisi pada formulir pendaftaran antara lain :

a. Username: Username yang diminta minimal 4 karakter dengan menggunakan huruf atau angka atau perpaduan dari keduanya.

b. Email

c. Phone

d. Password: Kata sandi yang diminta minimal 6 karakter.

e. Confirm password: Ruas ini diisi sama persis dengan kata sandi (password) 
Bibliotech : Jurnal Ilmu Perpustakaan dan Informasi, 3 (2) 2018

Jika terjadi kesalahan/ketidaksesuaian informasi yang diminta maka akan terdapat peringatan berwarna merah pada bagian atas formulir. Beberapa peringatan yang biasa terjadi disebabkan oleh:

a. Ruas yang diminta tidak diisi akan muncul peringatan " $<$ nama ruas $>$ is required"

b. Username kurang dari 4 karakter akan ditampilkan pesan "The Username field must be at least 4 characters in length."

c. Username sudah digunakan akan ditampilkan pesan "This username already exists. Please choose another one."

d. Email yang tidak benar/valid akan ditampilkan pesan "The Email field must contain a valid email address."

e. Password tidak sama dengan ruas Confirm password akan ditampilkan pesan "The Confirm Password field does not match the Password field."

Setelah pendaftaran berhasil dilakukan maka partisipan akan diarahkan ke halaman Login. Login dapat dilakukan dengan memasukkan username serta password yang sudah didaftarakan sebelumnya. Login yang berhasil akan diarahkan ke halaman tunggu. Terdapat informasi bahwa akun yang baru saja dibuat masih menunggu verifikasi dari administrator.

Akun yang telah diverifikasi oleh administrator dapat memulai kegiatan penginputan subjek. Alur penginputan subjek terdiri dari beberapa langkah, lihat Gambar 6. Proyek ValCoN menggunakan DTS Perpusnas sebagai acuan dalam penginputan subjek, sehingga perlu dipersiapkan terlebih dahulu DTS Perpusnas sebelum melakukan penginputan. DTS Perpusnas dapat diunduh secara gratis dalam bentuk PDF pada alamat http://pusbangkol.perpusnas.go.id/downlot.php?file=tajuksubjek_pnri.pdf. 
Bibliotech : Jurnal Ilmu Perpustakaan dan Informasi, 3 (2) 2018

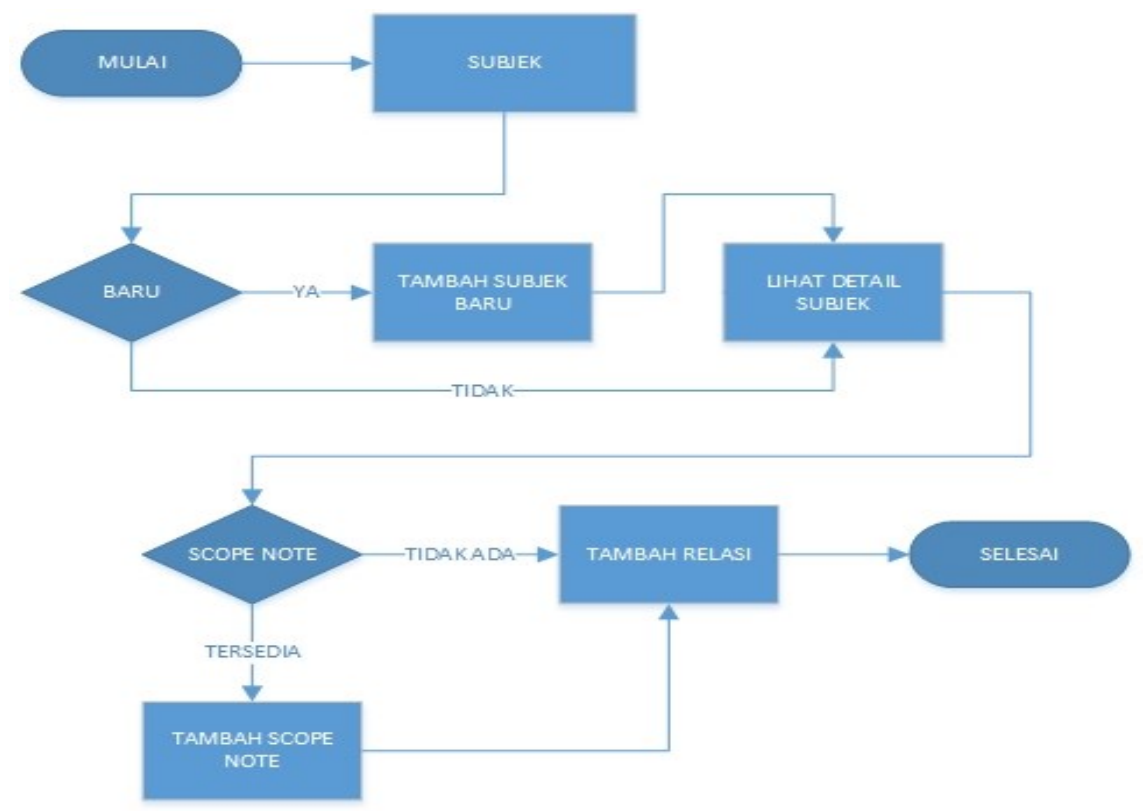

Gambar 6. Diagram alur penginputan.

Untuk memulai penginputan dapat dilakukan dengan mengunjungi Menu Topic atau mengakses alamat http://slimsjakarta.web.id/vocabulary/topic. Kemudian klik pada tombol Add Topic, maka akan muncul popup formulir isian untuk menambah subjek baru. Penulisan subjek utama pada DTS Perpusnas ditulis dengan huruf tebal, sedangkan subsubjek ditulis dengan format huruf normal. Untuk membedakan mana subjek utama dan mana sub-subjek dalam proyek ValCoN, digunakan aturan sebgai berikut:

a. Subjek utama ditulis dengan huruf kapital (uppercase)

Contoh: ABSENSI (PEKERJA), ADHESI ELEKTROSTATIK

b. Sub-subjek ditulis dengan huruf kecil (lowercase)

Contoh: Bolos, Buruh, Pekerja. (Lihat Gambar 7) 
Bibliotech : Jurnal Ilmu Perpustakaan dan Informasi, 3 (2) 2018

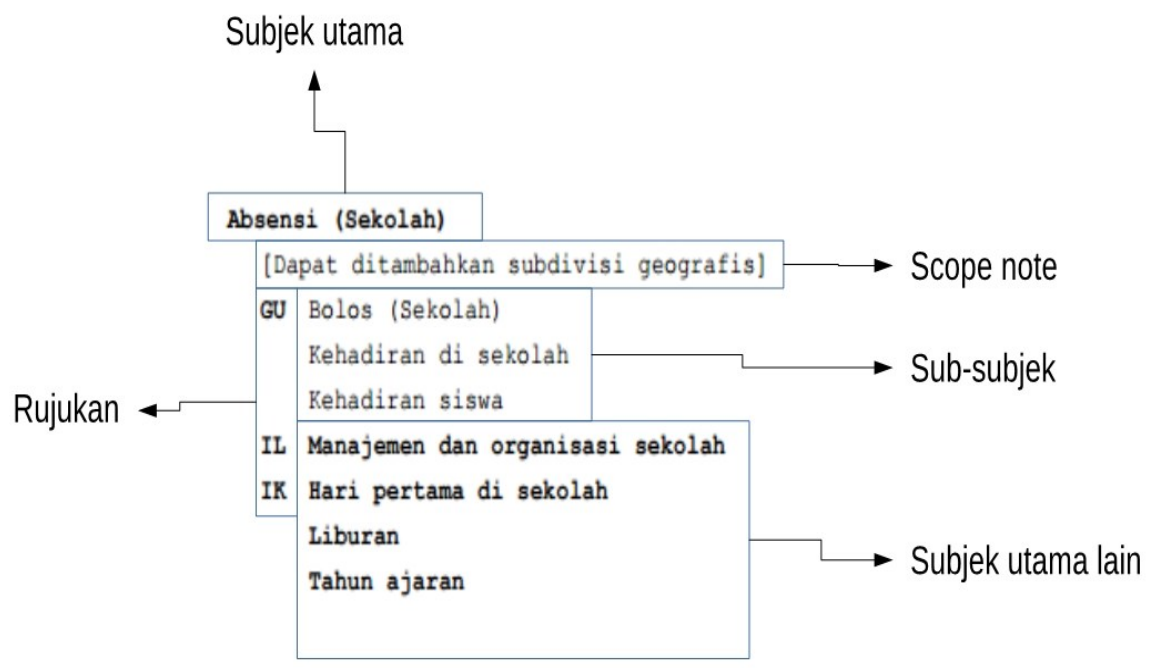

Gambar 7. Bagian-bagian penulisan subjek pada DTS Perpusnas.

Dengan demikian, langkah-langkah dalam penginputan subjek pada proyek ValCoN sebagai berikut:

1. Menambahkan subjek utama sebagai subjek baru dengan cara klik pada tombol Add Topic, masukan subjek utama (Absensi (Sekolah)) pada ruas Topic dengan huruf kapital (uppercase), sehingga menjadi ABSENSI (SEKOLAH), lihat Gambar 8.

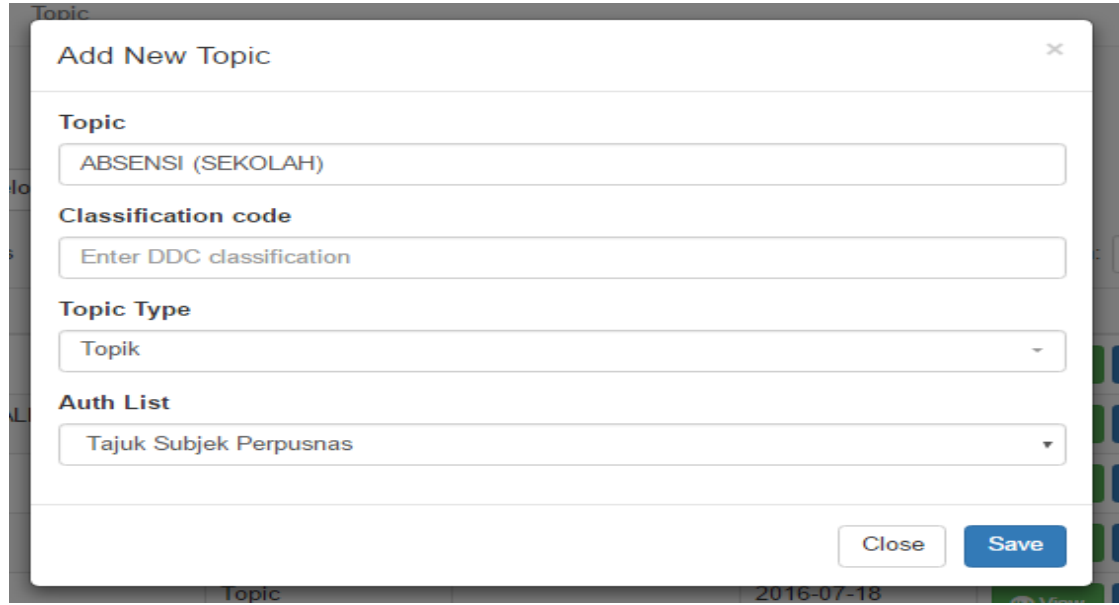

Gambar 8. Menambahkan subjek baru.

2. Isikan notasi DDC pada ruas Classification Code jika tersedia.

3. Pilih salah satu Topic Type sesuai dengan subjek yang diinputkan. 
Menurut Sulistio-Basuki (2011) terdapat empat macam jenis tajuk subjek:

a. Tajuk topik

Tajuk topik adalah kata atau frasa untuk benda atau konsep sehari-hari yang mewakili isi berbagai karya.

b. Tajuk bentuk

Tajuk bentuk tidak menguraikan isi subjek sebuah karya melainkan bentuk karya. Bentuk dalam konteks ini bermakna bentuk intelektual dari materi perpustakaan bukannya bentuk fisik materi tersebut.

c. Tajuk geografi

Tajuk geografi merupakan nama sebuah tempat / kawasan yang sudah mapan. Tajuk geografi berbeda dari tajuk subjek topik karena tajuk geografi merupakan entitas unik, bukannya abstraksi benda.

d. Tajuk nama

Koleksi sebuah perpustakaan lazimnya mencakup juga karya tentang seseorang, keluarga, badan korporasi, karya sastra, film, dll. Tajuk yang sesuai bagi karya tersebut adalah nama unik dari entitas yang bersangkutan

4. Klik tombol Save jika untuk menyimpan subjek baru ke dalam database. Jika subjek yang dimasukan sudah tersedia maka akan ditampilkan peringatan bahwa subjek sudah tersedia dengan pesan error "Error adding or update data or topic already exist."

Jika subjek berhasil disimpan maka akan muncul pada baris pertama daftar subjek.

5. Selanjutnya klik tombol View pada daftar subjek untuk subjek yang baru saja ditambahkan. Gunakan fasilitas pencarian jika kesulitan dalam menemukan subjek yang baru saja diinputkan, lihat Gambar 9.

\begin{tabular}{|c|c|c|c|c|c|c|c|c|c|c|}
\hline \multirow{2}{*}{$\begin{array}{c}\text { Show } \\
\text { Topi }\end{array}$} & \multirow[t]{2}{*}{$10 \quad$ entries } & & & & & \multicolumn{3}{|r|}{ Search: } & \multicolumn{2}{|c|}{ absensi (sekolah) } \\
\hline & & \1 & Topic Type & $\downarrow \uparrow$ & Classification & \1 & Input Date & Action & & \\
\hline \multicolumn{3}{|c|}{ ABSENSI (SEKOLAH) } & Topic & & & & 2016-04-10 & OView & Edit & 亩 Delete \\
\hline \multicolumn{3}{|c|}{ Topic } & Topic Type & & Classification & & Input Date & Action & & \\
\hline Showir & g 1 to 1 of 1 entrie & om 3 & 051 total entri & & & & & & Previous & Next \\
\hline
\end{tabular}

Gambar 9. Pemanfaatan fasilitas pencarian.

6. Klik pada tombol Add Scope untuk menambahkan scope note pada subjek. Kemudian isikan scope note pada subjek tersebut, lihat Gambar 10. 


\section{Add Scope}

Scope for this topic relation

Dapat ditambahkan subdivisi geografis

\section{Gambar 10. Menambahkan scope note subjek.}

Jika scope note berhasil ditambahkan maka akan tampil di atas tabel relasi, tombol Add Scope akan berganti menjadi tombol Edit Scope. Hal ini menunjukkan bahwa scope note hanya ada satu untuk setiap subjek.

7. Untuk menambahkan relasi/hubungan subjek utama dengan subjek lain dapat menggunakan tombol Add Relation. Saat tombol diklik akan muncul popup form untuk menambahkan relasi subjek yang terdiri dari beberapa ruas diantaranya relation term (rujukan), Subject (subjek yang akan direlasikan dengan subjek utama), Classification Code, Subject Type.

Saat menginputkan pada ruas Subject System akan mencari subjek yang sudah tersedia, sehingga dapat langsung dipilih, hal ini meminimalisir terjadinya duplikasi data serta menjaga keseragaman penulisan. Pengisian ruas Subject juga dapat dilakukan sekaligus untuk subjek yang banyak dengan relation term yang sama, lihat Gambar 11. 


\section{Add Topic Relation}

\section{Relation term}

Use For | Gunakan Untuk

Subject

$x$ bolos (sekolah) $-\mathrm{t} \times$ kehadiran di sekolah $-\mathrm{t}$ Kehadil

Kehadi

kehadiran di sekolah -t

kehadiran siswa $-\mathrm{t}$

Subject lype

Topik

Gambar 11. Penginputan ruas subject dapat dilakukan lebih dari satu.

Jika subjek sudah tersedia pada pangkalan data maka untuk ruas Classification Code serta Subject Type tidak perlu diisi. Namun jika subjek yang direlasikan belum tersedia pada pangkalan data kedua ruas tersebut dapat diisi sehingga saat relasi disimpan maka subjek tersebut akan disimpan sebagai subjek baru.

\section{KESIMPULAN}

Proyek ValCoN merupakan kegiatan yang memfokuskan pada pengalihan bentuk daftar subjek ke dalam basisdata. Artikel ini memberikan gambaran fitur-fitur yang tersedia serta alur kerja pada proyek ValCoN. Artikel ini dapat dijadikan sebagai pedoman bagi partisipan proyek ValCoN yang hendak dan telah bergabung pada proyek ValCoN. Dengan demikian meskipun para partisipan berasal dari berbagai macam latar belakang keilmuan dan profesi, kosakata terkendali hasil kegiatan ini akan tetap seragam.

\section{DAFTAR PUSTAKA}

Kangko, D. D. (2016). “Implementasi Bahasa Indeks Pada Senayan Library Management System (SLIMS)". Lokakarya Nasional Dokumentasi dan Informasi: Pengelolaan 
Bibliotech : Jurnal Ilmu Perpustakaan dan Informasi, 3 (2) 2018

Data, Informasi dan Pengetahuan untuk Mendukung Pembangunan Repositori. Kumpulan Makalah Lokakarya Nasional 2016 (pp. 151-163). Jakarta: PDII LIPI.

Hasibuan, Z. A. (2007). Metodologi penelitian pada bidang ilmu komputer dan teknologi informasi: konsep, teknik, dan aplikasi. Depok: Fasilkom Universitas Indonesia.

Purwono. (2011). Dasar-dasar Dokumentasi. Retrieved November 21, 2016, from http://www.pustaka.ut.ac.id/lib/2016/08/08/pust2241-dasar-dasar-dokumentasi/

Sulistyo-Basuki. (2011). "Tajuk Subjek dalam Konteks Pengajaran dan Penggunaannya di Perpustakaan Indonesia". Visi Pustaka, 13(1). Retrieved from http://perpusnas.go.id/magazine/tajuk-subjek-dalam-konteks-pengajaran-danpenggunaannya-di-perpustakaan-indonesia/ 
Bibliotech : Jurnal Ilmu Perpustakaan dan Informasi, 3 (2) 2018 